\title{
Development of Inquiry-Based Science Laboratory Module for Science Teachers
}

\author{
Eka Trisianawati ${ }^{1}$, Ira Nofita Sari ${ }^{1}$, and Nurussaniah ${ }^{1}$ \\ ${ }^{1}$ IKIP PGRI Pontianak, Pontianak, Indonesia \\ trisianawatieka@gmail.com
}

\begin{abstract}
This study aimed to develop and determine the quality of inquiry-based science practicum modules for science teachers and find out the teacher's response in using the inquiry-based science practicum modules. This research adopted Research and Development (R\&D) method by Borg \& Gall (2003). The data collection was performed by indirect communication using an expert validation questionnaire to determine the quality of the module, and the response questionnaire to find out the teacher's response to inquiry-based science practicum modules. The results showed that inquiry-based science practicum modules for science teachers could be developed and had decent quality based on the material (76.85) and media experts (81.18). Teachers' responses to inquiry-based science practicum modules were classified very well with a percentage of $89.31 \%$. The development of inquiry-based science practicum modules was expected to be used as reference material for science teachers in implementing practicum, which is one way to implement scientific processes and scientific attitudes in science learning.
\end{abstract}

\section{Introduction}

Science learning is essentially a science that studies phenomena that occur in nature and interactions in them. One component of education that is very important in the learning process is a module, which is a source of learning used by teachers and students to obtain information and as a guide in learning activities. According to Matsun, Anggraeni, \& Trisianawati (2019), integrated teaching material is very useful to support the integrated science learning process in SMP/ MTs. modules are one of the most important components in the learning process. The availability of modules can help students obtain information about learning material. According to Nurhidayah (2015), learning material can make students study independently in addition to learning in the classroom. Independent learning can be achieved by using a module.

Based on the questionnaire given to respondents who were members of the Junior High School Science Teachers Forum (MGMP) of Kubu Raya Regency in April 2017, 65\% of the teachers stated that lab practices were rarely carried out at school, $25 \%$ of them stated that lab practices were only carried out for trial subjects conducted during practical exams, and only $10 \%$ of teachers stated that lab 
practices were often conducted at school (Nurussaniah, Trisianawati, \& Sari, 2017). Moreover, most of the lab practices $(40 \%)$ were not supported by a lab module even though the lab activity was already performed. According to Aulia, Zulhendra, \& Jaya (2014), the module provides opportunities for students to learn according to the different techniques used to solve different problems, based on the background of their respective knowledge and habits. Novianty, Oktavia \& Neena (2013) found that the effectiveness of modules can improve students' learning outcomes, observed from the different average values between the experimental class (78.57) and control class (71.38). Trisianawati \& Darmawan (2017) stated that the use of modules based on implementation can improve students' science process skills both at the basic and integrated levels from $64.25 \%$ to $74.5 \%$

Permendiknas RI No. 22 (2006) explained that Natural Science (IPA) is a science of nature that is obtained through a scientific method which is observing, formulating problems, hypothesizing, collecting data, analyzing data, proving hypotheses, concluding, and communicating. Therefore, teaching science is not just explaining the theoretical knowledge, but the students must get direct experience so that the knowledge gained becomes more meaningful. The science learning process emphasizes giving direct experience to develop competencies to explore and understand the natural environment in a scientific manner. Based on the description above, this study aimed to develop and determine the quality of inquiry-based science lab modules for science teachers and find out teachers' responses to the inquiry-based science lab modules for science teachers.

\section{Materials and Methods}

The method used in this study was research and development based on Borg \& Gall (Gall, 2013) which at this initial stage only carried out three stages, namely research and information collecting, planning, and developing a preliminary form of the product. The instruments used to collect data in this study were observation sheets, development plan sheets, and product validation questionnaires. Observation sheets were used to record information about the needs of the measurement and literature study. The plan sheet was used to record and compile a research development plan including the abilities needed in conducting the research, the formulation of the objectives to be achieved, and the design or steps of the research. The product validation questionnaire was used to facilitate the validator to assess the feasibility of the product being developed. Data analysis used in this research was qualitative and quantitative descriptive analysis. Qualitative descriptive analysis was used to describe the implementation of the research and information collecting stage and planning, whereas quantitative descriptive analysis using a Likert scale was used to describe the results of product validation by the validator.

The quality of the inquiry-based science practicum modules developed was assessed based on input from the validators. The validators consisted of three material experts and three media experts. Data from validation sheets in the form of quantitative data analyzed descriptively to find a strength or a weakness of the module quality based on the assessment of material experts and media experts in percentage. Percentages were obtained based on the quotient between scores which was obtained with a maximum score. Module quality criteria were then determined by the percentage given by the validators. The obtained percentage was scored using the criteria as listed in Table 1 based on Muhafid, Dewi \& Widiyatmoko (2013). Moreover, the teacher's response to the inquiry-based science lab practice module was analyzed using percentage, obtained from the response questionnaire was then interpreted into criteria according to Muhafid, Dewi \& Widiyatmoko (2013) as presented in Table 2.

\begin{tabular}{cll}
\hline No. & \multicolumn{1}{c}{ Score } & \multicolumn{1}{c}{ Criteria } \\
\hline 1. & $81.25 \%<$ score $\leq 100 \%$ & Highly Feasible \\
2. & $62.50 \%<$ score $\leq 81,25 \%$ & Feasible \\
3. & $43.75 \%<$ score $\leq 62,50 \%$ & Less Feasible \\
\hline
\end{tabular}




4. $25.00 \%<$ score $\leq 43,75 \% \quad$ Not Feasible

Table 1: Score percentage criteria of module quality assessment result according to Muhafid, Dewi, \& Widiyatmoko (2013)

\begin{tabular}{cll}
\hline No. & \multicolumn{1}{c}{ Score } & \multicolumn{1}{c}{ Criteria } \\
\hline 1. & $75 \%<$ score $\leq 100 \%$ & Very Strong \\
2. & $50 \%<$ score $\leq 75 \%$ & Strong \\
3. & $25 \%<$ score $\leq 50 \%$ & Weak \\
4. & Score $\leq 25 \%$ & Very weak \\
\hline
\end{tabular}

Table 2: Score percentage criteria of response assessment result according to Muhafid, Dewi, \& Widiyatmoko (2013)

\section{Results and Discussions}

This is development research using the design of Borg and Gall (2003) which at this initial stage only carried out three stages, namely research and collecting information, planning, and developing a preliminary form of the product. The development steps taken in this study can be seen in Figure 1 . This research is an initial study on the development of a science practicum module for the inquiry teaching model. The development steps that have been taken were research and information collage, planning, and developing a preliminary form of the product.

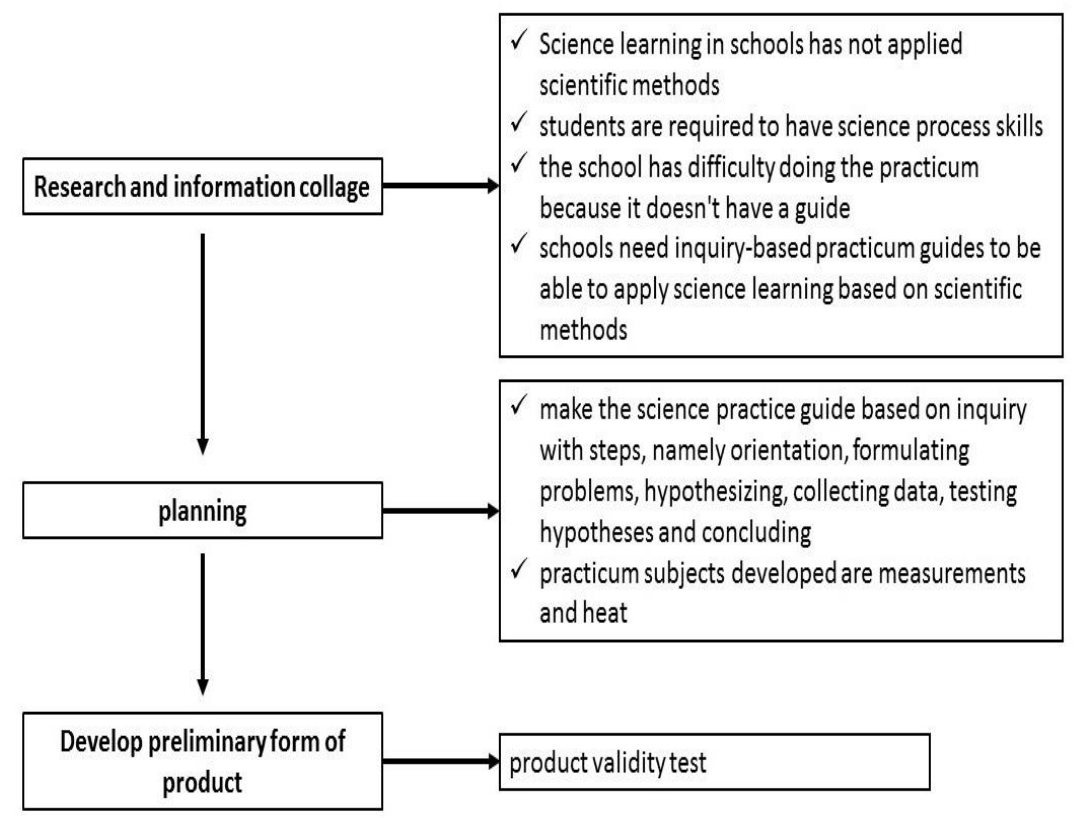

Figure 1: Steps for developing the inquiry-based science practice guide

At the planning stage, we made the science practice guide based on inquiry teaching model which consisted of the following steps, namely orientation, formulating problems, hypothesizing, collecting data, testing hypotheses, and concluding based on Sudi, Yusuf \& Nurhayati (2016). The development result of the product can be seen in Figure 1. 


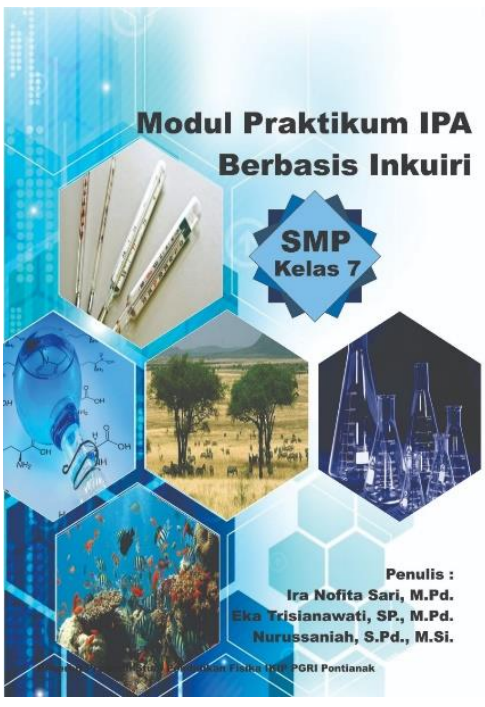

A

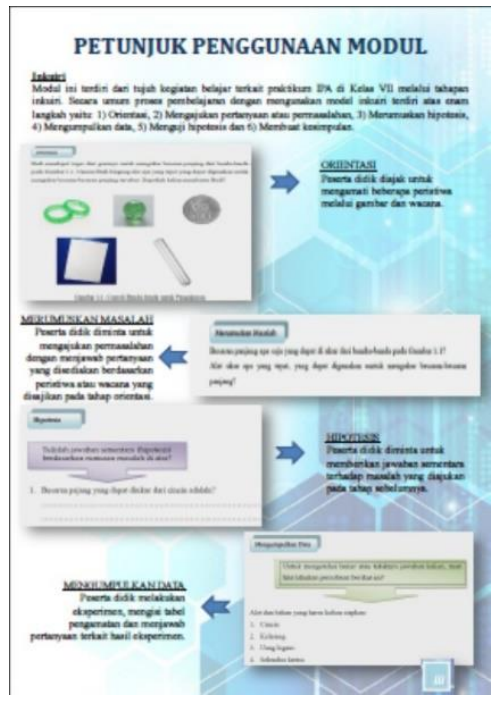

$\mathrm{C}$

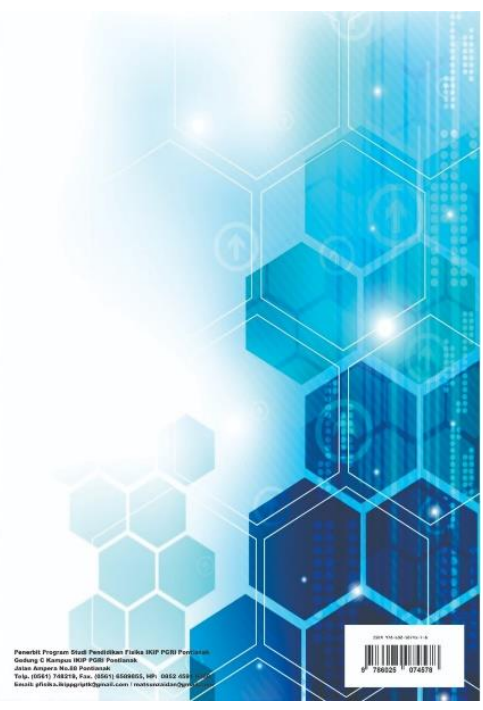

B

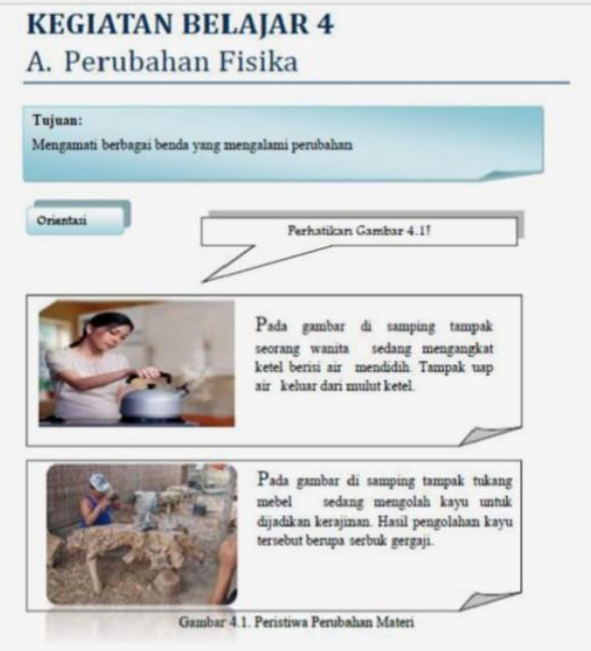

$\mathrm{D}$

Figure 2: The development product of inquiry-based science practicum module for science teachers; A and B. cover and back side, C. using guidance, D. student's activity.

In general, the inquiry-based science practicum module for natural science teachers that was developed was considered feasible by material experts to be used in learning with an average rating of three validators is 76.85 . This is seen from the suitability of the content with the Standard and Basic Competences in the curriculum. Besides, the depth of the material presented in the module was following the standard and basic competences contained in the curriculum, as well as the indicators and learning objectives. The material in the developed module was presented accurately to avoid misconceptions that might arise from students. Besides, the material contains descriptions, examples, or questions that explain the application of the concept of science in everyday life, so that it attracts and 
arouses students' interest to study further. The presentation of the material is interactive and participatory so that the module content is easier to understand. The language used in the module is in accordance with good and correct Indonesian language rules and is adapted to the abilities of students and teachers.

Inquiry-based science practicum modules for science teachers developed with very decent criteria 81.18. The graphics contained in the developed teaching material are reviewed in terms of the type and size of the fonts as well as the illustrations, images, and photos used that are appropriate and proportional to the font size 11 and use the font types Cambria (Headings), Footlight MT Light, and Times New Roman. These types of letters were chosen because of their attractive shape so that the impression of the book is not rigid so that students are interested in reading information other than the subject matter that is in teaching material. The illustrations, drawings, and photos were in accordance with the concepts conveyed. The validation results of the inquiry-based science practicum modules for science teachers can be seen in Table 3 .

\begin{tabular}{lcc}
\hline & Average & Criteria \\
\hline Material Expert & 76.85 & Feasible \\
Media Expert & 81.18 & Highly Feasible \\
\hline
\end{tabular}

Table 3: The Results of the Validation of the Science Module -based Inquiry Models for Science Teacher by Validator

The revised inquiry-based science practicum module for the science teacher according to the validator's suggestions and comments was used at the next stage of the product trial. The product trial was conducted at SMPN 4 Pontianak. In the inquiry learning model using the module, students were involved in many scientific activities and thinking processes to build new knowledge. It was known that the design of inquiry-based science practicum modules for science teachers was considered very good with a percentage of $89.31 \%$. In this case, respondents showed a very strong response in most aspects of assessment. In detail, the results of the teacher's response to the inquiry-based science practicum module for science can be seen in Table 4.

\begin{tabular}{clc}
\hline No & \multicolumn{1}{c}{ Aspects of Assessment } & Percentage \\
\hline 1 & Authorization concept & 100 \\
2 & The depth of the concept & 75.00 \\
3 & The level of practical & 87.50 \\
4 & Sentence clarity and readability & 98.35 \\
5 & Charge inquiry approach & 100 \\
6 & Physical appearance & 75.00 \\
& Average & 89.31 \\
& Criteria & Very good \\
\hline
\end{tabular}

Table 4: The teachers' response on each aspect of assessment on the inquiry-based science laboratory module

According to Wahyudi, Fadillah, \& Saputri (2015), learning instruments developed based on inquiry approaches can be used to improve problem-solving skills. Also, the use of inquiry stages in an effective module influences students' learning independence (Nurhayati., Saputri, \& Sari, 2015). In practical terms, the development of inquiry-based science practicum modules is expected to be used as reference material for science teachers in implementing practicum, which is one way to implement scientific processes and scientific attitudes in science learning. Based on the results of the study, it can be concluded that the science practicum module can be developed based on the inquiry learning model. In this case, the inquiry learning model as presented in the science laboratory module can be used as an 
alternative to traditional teacher-centered learning and learning practices that emphasize textbooks.

\section{Acknowledgment}

The authors thank Kemenristekdikti for the research funding under contract number 023/L.202.103/PDP/III/2018 and LPPM IKIP PGRI Pontianak and administrative support for this study.

\section{References}

Sudi AB, Yusuf MN, and Nurhayati. (2016). Pengaruh Metode Pembelajaran Inkuiri pada Subtema Gerak dan Gaya Terhadap Hasil Belajar Siswa Kelas IV SDN 16 Banda Aceh. In Bahasa. Jurnal Pesona Dasar. 3(4): 73-83.

Aulia F, Zulhendra M, and Jaya P. (2014). Pengaruh Penggunaan Modul pada Model Pembelajaran Kooperatif Tipe Student Team Achievement Divisions terhadap Hasil Belajar Siswa pada Mata Pelajaran Keterampilan Komputer dan Pengelolaan Informasi di SMK Negeri 2 Bukittinggi. In Bahasa. Jurnal Vokasional Teknik Elektronika \& Informatika, 2(1): 1-14.

Trisianawati E and Darmawan H. (2017). Pengembangan Lembar Kegiatan Mahasiswa Berbasis Model Guided Inquiry untuk Meningkatkan Keterampilan Proses Sains Mahasiswa. In Bahasa. VOX EDUKASI: Jurnal Ilmiah Ilmu Pendidikan. 8(2): 60-71.

Gall MD, Borg WR, and Gall J. (1996). Educational Research: An Introduction. Sixth Edition, New York: Longman.

Muhafid EA, Dewi NR, and Widiyatmoko A. (2013). Pengembangan Modul IPA Terpadu Berpendekatan Keterampilan Proses pada Tema Bunyi di SMP Kelas VIII. In Bahasa. Unnes Science Education Journal. 2(1): 140-148.

Matsun M, Anggraeni L, and Trisianawati E. (2019). Pengembangan Buku Ajar IPA Terpadu SMP berbasis Eksperimen. In Bahasa. Lectura: Jurnal Pendidikan. 10(2). 107-122.

Novianty I, Oktavia S, and Neena Z. (2013). Efektivitas Penerapan Modul Materi Analisis Elektrokimia Berbasis Inkuiri Terbimbing terhadap Hasil Belajar dan Persepsi Siswa Kelas XI Semester 1 Kompetensi Keahlian Kimia Analisis SMKN 7 Malang. In Bahasa. Jurnal Online Universitas Negeri Malang: Pendidikan Kimia. 1(2): 1-7.

Nurhidayah R, Irwandi D, and Saridewi N. (2015). Pengembangan modul berbasis inkuiri terbimbing pada materi larutan elektrolit dan non-elektrolit. In Bahasa. EDUSAINS, 7(1), 36-47.

Nurussaniah, Trisianawati E, and Sari IN. (2017). Pembelajaran Inkuiri untuk Meningkatkan Keterampilan Proses Sains Calon Guru Fisika. In Bahasa. Jurnal Ilmiah Pendidikan Fisika Al Biruni. 06(2): 233-240.

Nurhayati, Saputri DF, and Sari IN. (2015). Efektivitas Penggunaan Modul Fisika Berbasis Inkuiri terhadap Hasil Belajar dan Kemandirian Belajar Mahasiswa. In Bahasa. Jurnal Pendidikan Informatika dan Sains. 4(2): 247-258.

Wahyudi, Fadillah S, and Saputri DF. (2015). Analisis Instrumen Pembelajaran Fisika Matematika Berbasis Pendekatan Inkuiri untuk Meningkatkan Kemampuan Pemecahan Masalah Matematika. In Bahasa. Prosiding Seminar Nasional Fisika SNF 2015. IV: 43-47. 